\title{
THEORETICAL ASPECTS OF MODIFICATION MECHANISM FOR SOL-GEL CERAMIC OXIDE POWDERS OF TECHNICAL APPLICATION
}

\author{
Iryna Lutsyuk ${ }^{1, *}$, Yaroslav Vakhula ${ }^{1}$
}

https://doi.org/10.23939/chcht12.03.386

\begin{abstract}
Liquid phase technologies for high-grade ceramic oxide powders of technical purpose and methods of their modification have been developed. On the basis of physico-chemical research methods various mechanisms of modifying processes have been analyzed. Substitution of the main ions by doping ones occurs in complex oxide powders followed by the formation of solid solutions. A powder which was obtained via $\mathrm{TiO}_{2}$ modification by sulfur has a surface layer in which sulfur forms chemical bonds.
\end{abstract}

Keywords: ceramic powders, structural modification, solgel technology, solid solutions, ion implantation.

\section{Introduction}

Modern ceramics with high performance are obtained using special compositions and microstructures, which require precision control at all technological stages: synthesis of powders with certain sizes, processes consolidation and formation, sintering, final heat treatment and control. The properties of technical ceramics depend on the properties, structure, purity, and granulometry of powders.

Ceramic oxide powders are necessary components of many materials, in particular, solid-state lasers, photocatalysts, plastics and heat-resistant concrete, dental composite materials, sorbents, etc. [1-4]. The main characteristics of ceramic powders are the chemical composition, their homogeneity, shape, particles size and granulometry, the degree of particles crystallinity and the concentration of nonequilibrium defects [5-6].

Despite the high functional indices of powders and ceramics in general, often it is expedient to introduce a small amount (even a fraction of one percent) of a certain additive without changing the basic composition of the

\footnotetext{
${ }^{1}$ Lviv Polytechnic National University

12, S.Bandery St., 79013 Lviv, Ukraine

*khts.dept@lpnu.ua

C Lutsyuk I., Vakhula Ya., 2018
}

powder to change its basic parameters radically. The range of technical characteristics of the powders may be extended due to their modification. Such approach allows to change or strengthen the operational properties of the product without changing the main operating conditions.

The choice of the method and degree of modification, as well as the type of modifying agent is an urgent problem from technological and economical viewpoint. It depends on the kind o technology, powder type and ultimate aim.

From kinetics and energy saving standpoint liquid phase technology and sol-gel technology in particular, is the most promising one [7-8]. This technology allows to modify the powder composition and structure at the stage of solutions preparation on the ionic level and to provide the maximum uniform distribution of the modifier in the mixture. Due to the proceeding of sol-gel process and modification at low temperatures the resulting effect is maximum positive.

The aim of this work is to study the mechanisms of modifying the structure of powders in order to change their properties and to obtain materials with given parameters.

\section{Experimental}

\subsection{Powders Synthesis}

Nanocrystalline oxide powders of forsterite $\mathrm{Mg}_{2} \mathrm{SiO}_{4}: \mathrm{Me}\left(\mathrm{Me}=\mathrm{Cr}^{3+}, \mathrm{Y}^{3+}, \mathrm{Zr}^{4+}\right)$, spinel $\mathrm{MgAl}_{2} \mathrm{O}_{4}: \mathrm{Me}$ $\left(\mathrm{Me}=\mathrm{Cr}^{3+}, \mathrm{Zr}^{4+}\right)$ and $\mathrm{S}-\mathrm{TiO}_{2}$ were synthesized via sol-gel technology.

Synthesis of $\mathrm{MgO}-\mathrm{SiO}_{2}$ powders. Magnesium acetate $\mathrm{Mg}\left(\mathrm{CH}_{3} \mathrm{COO}\right)_{2} \cdot 4 \mathrm{H}_{2} \mathrm{O}$ (P.A. grade) was dissolved in water and ethyl silicate ETS-40 was slowly hydrolyzed in the presence of chloric acid. The obtained solutions were mixed at the definite molar ratio and sol was formed transformed further into a gel. The gel was dried at 383-388 K for 35-40 $\mathrm{h}$. To form the final powder with the given phase composition the gel was treated at $1173 \mathrm{~K}$ for $3 \mathrm{~h}$. 
Synthesis of $\mathrm{MgO}-\mathrm{Al}_{2} \mathrm{O}_{3}$ powders. Magnesium acetate $\mathrm{Mg}\left(\mathrm{CH}_{3} \mathrm{COO}\right)_{2} \cdot 4 \mathrm{H}_{2} \mathrm{O}$ (P.A. grade), aluminum nitrate $\mathrm{Al}\left(\mathrm{NO}_{3}\right)_{3} \cdot 9 \mathrm{H}_{2} \mathrm{O}$ (P.A. grade) and citric acid (CA) were dissolved in water and mixed with the molar ratio of $n\left(\mathrm{Mg}^{2+}+\mathrm{Al}^{3+}\right): n(\mathrm{CA})=1: 1$. The solution was evaporated at the temperature about $363 \mathrm{~K}$ until a polymer gel was obtained. Then it was burned out at $1273 \mathrm{~K}$ for $3 \mathrm{~h}$.

To vary the properties of forsterite and spinel their structures were modified by $\mathrm{Cr}^{3+}, \mathrm{Y}^{3+}$ and $\mathrm{Zr}^{4+}$ ions, which were introduced using water-soluble salts $\mathrm{Cr}\left(\mathrm{NO}_{3}\right)_{3} \cdot 9 \mathrm{H}_{2} \mathrm{O}$, $\mathrm{Y}\left(\mathrm{NO}_{3}\right)_{3} \cdot 6 \mathrm{H}_{2} \mathrm{O}$ and $\mathrm{ZrOCl}_{2} \cdot 8 \mathrm{H}_{2} \mathrm{O}$. All salts were of pure grade.

Synthesis of $\mathrm{S}-\mathrm{TiO}_{2}$ powders. To obtain powders of titanium(IV) oxide modified by sulfur we used titanium butoxide $\mathrm{Ti}\left(\mathrm{C}_{4} \mathrm{~N}_{9} \mathrm{O}\right)_{4}(\mathrm{TBO})$, thiourea $\left(\mathrm{NH}_{2}\right)_{2} \mathrm{CS}$ (TU) and butanol. TBO was previously hydrolyzed in ethanol, butanol and water. TU was dissolved in water. The obtained solutions were mixed at the definite molar ratio until a sol was formed. Then the sol was dried by two stages: I stage - at $393 \mathrm{~K}$ to obtain the paste-like mixture; II stage - at $513 \mathrm{~K}$ to obtain the powder.

The first stage of sol drying was carried out using three modes: $\tau=96 \mathrm{~h})$

mode 1 - natural weathering of the sols $(T=293 \mathrm{~K}$,

mode 2 - heat treatment of the sols with simultaneous mixing and heating $(T=373 \mathrm{~K}, \tau=24 \mathrm{~h})$;

mode 3 - hydrothermal treatment of sols in an autoclave ( $T=383 \mathrm{~K}, \tau=24 \mathrm{~h}$ ).

The dried sols were burned out within the temperature range of $673-973 \mathrm{~K}$ for $1 \mathrm{~h}$.

\subsection{Investigation Methods}

X-ray diffraction analysis (XRD) was carried out using DRON-4 diffractometer with the following mode of operation: $\mathrm{Cu} \mathrm{K} \alpha$ radiation; $2 \theta=10^{\circ}-80^{\circ} ; U=34 \mathrm{kV}$; $I=14 \mathrm{~mA}$. The surface composition was studied by X-ray photoelectron spectroscopy (XPS) using XSAM-800 Kratos spectrophotometer. The surface composition was estimated by the area of obtained bands. The thickness of the analyzed layer was approximately $5 \mathrm{~nm}$.

SEM analysis was carried out using ZEISS EVO 40XVP microscope with the system of X-ray microanalysis INCA Energy. The same system was also used for X-ray emission spectroscopy (XES) to analyze quantitative and qualitative composition of the powders.

The unit cell dimensions, as well as positional and displacement parameters of atoms in the structures were derived by full profile Rietveld refinement technique using software package WinCSD [9].

The particle sizes were determined according to the Scherrer equation.

\section{Results and Discussion}

$\mathrm{MgO}-\mathrm{SiO}_{2}$ powders. The results of $\mathrm{XRD}$ analysis confirmed that all pure and modified $\mathrm{Mg}_{2} \mathrm{SiO}_{4}$ powders are monophase and are represented by one crystalline phase - forsterite (Fig. 1). Other phases were not observed.

The calculated adjusted values of parameters and volumes of forsterite powder elementary cells are given in Table 1.

More precise definition of $\mathrm{Mg} / \mathrm{Cr}, \mathrm{Mg} / \mathrm{Y}$ and $\mathrm{Mg} / \mathrm{Zr}$ positions showed that $\mathrm{Mg}^{2+}$ ions are partially substituted by $\mathrm{Cr}^{3+}, \mathrm{Y}^{3+}$ and $\mathrm{Zr}^{4+}$ in $\mathrm{Mg} 2$ position. As a result of calculations using WinCSD software the percentage content of chromium, yttrium, and zirconium were found to be $1.18,0.59$ and $2.47 \mathrm{wt} \%$ or 0.46 , 0.13 and 0.55 at $\%$, respectively. In this case solid solutions are formed corresponding to the formulas: $\mathrm{Mg}_{1.97} \mathrm{Cr}_{0.03} \mathrm{SiO}_{4+\delta}, \quad \mathrm{Mg}_{1.99} \mathrm{Y}_{0.01} \mathrm{SiO}_{4+\delta} \quad$ and $\mathrm{Mg}_{1.96} \mathrm{Zr}_{0.04} \mathrm{SiO}_{4+\delta}$, respectively.

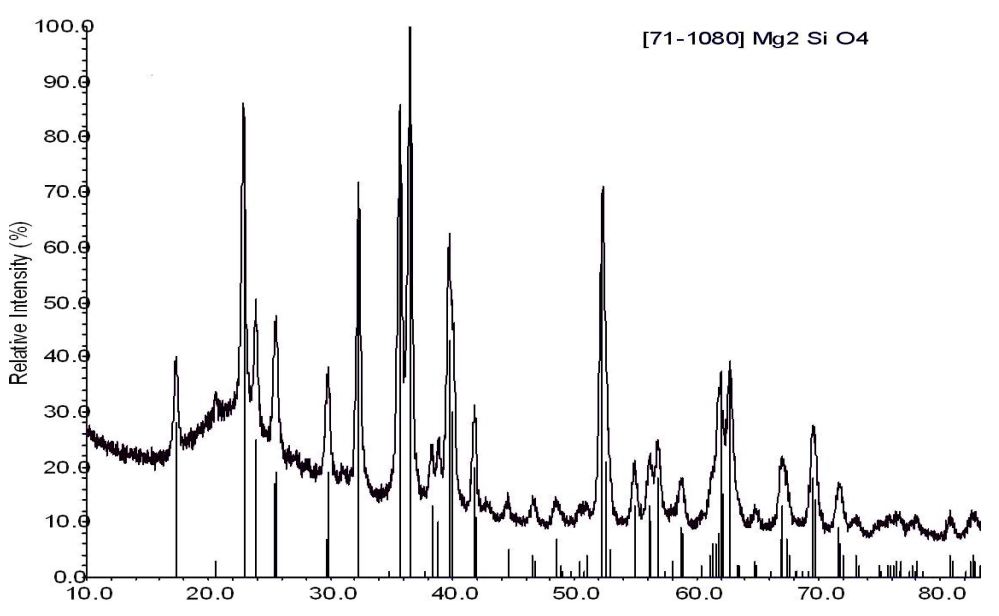

Fig. 1. Diffractogram of forsterite compared with $\mathrm{Mg}_{2} \mathrm{SO}_{4}$ standard diffractogram from the database PDF-2 
Parameters of forsterite powder elementary cells

\begin{tabular}{|c|c|c|c|c|}
\hline \multirow{2}{*}{ Parameters of elementary cell, $\AA$} & \multicolumn{4}{|c|}{ Powder } \\
\cline { 2 - 5 } & $\mathrm{Mg}_{2} \mathrm{SiO}_{4}$ & $\mathrm{Mg}_{2} \mathrm{SiO}_{4}: \mathrm{Cr}^{3+}$ & $\mathrm{Mg}_{2} \mathrm{SiO}_{4}: \mathrm{Y}^{3+}$ & $\mathrm{Mg}_{2} \mathrm{SiO}_{4}: \mathrm{Zr}^{4+}$ \\
\hline$a$ & $4.7569(4)$ & $4.7507(3)$ & $4.7517(2)$ & $4.7550(2)$ \\
\hline$b$ & $10.2175(9)$ & $10.2034(7)$ & $10.2099(4)$ & $10.2146(5)$ \\
\hline$c$ & $5.9886(5)$ & $5.9806(4)$ & $5.9849(4)$ & $5.9847(3)$ \\
\hline$V$ & $291.07(8)$ & $289.90(6)$ & $290.35(3)$ & $290.68(4)$ \\
\hline
\end{tabular}

Table 2

Parameters of spinel powder elementary cells

\begin{tabular}{|c|c|c|c|}
\hline \multirow{2}{*}{ Parameters of elementary cell, $\AA$} & \multicolumn{3}{|c|}{ Powder } \\
\cline { 2 - 4 } & $\mathrm{MgAl}_{2} \mathrm{O}_{4}$ & $\mathrm{MgAl}_{2} \mathrm{O}_{4}: \mathrm{Cr}^{3+}$ & $\mathrm{MgAl}_{2} \mathrm{O}_{4}: \mathrm{Zr}^{4+}$ \\
\hline$a$ & $8.0630(1)$ & $8.0640(1)$ & $8.0628(3)$ \\
\hline$V$ & $524.19(3)$ & 524.38() & $524.15(5)$ \\
\hline
\end{tabular}

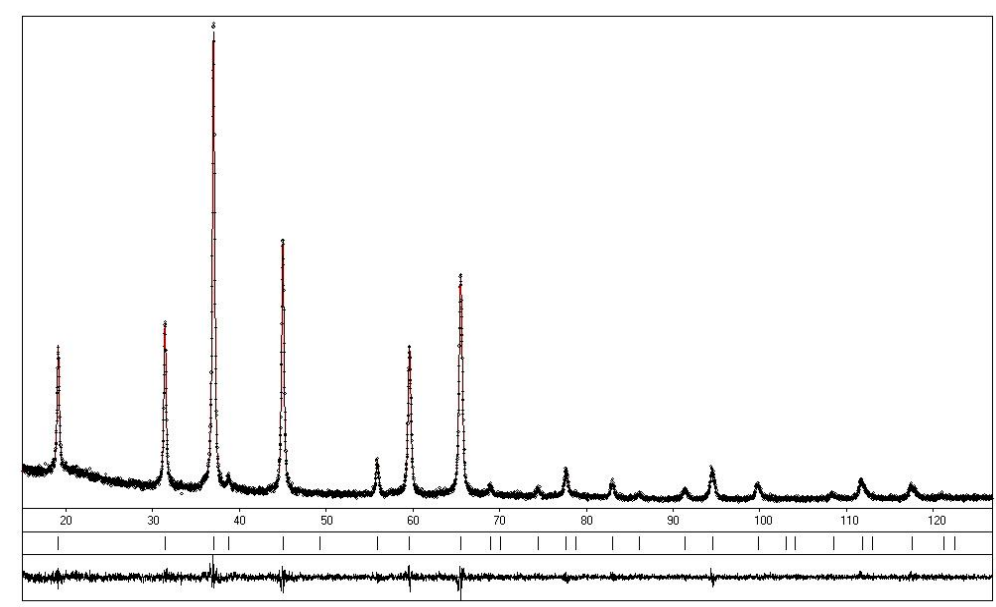

Fig. 2. Diffractogram of spinel powder $(T=1273 \mathrm{~K}, \tau=3 \mathrm{~h})$

The size of forsterite powder particles was determined using the expansion of diffraction maxima by the Scherrer method. They were found to be within the range of $35-40 \mathrm{~nm}$.

$\mathrm{MgO}-\mathrm{Al}_{2} \mathrm{O}_{3}$ powders. The peculiarity of sols for spinel preparation is the presence of citric acid (CA) as a gelling component in their composition. According to the experimental results the ratio of $n\left(\mathrm{Mg}^{2+}+\mathrm{Al}^{3+}\right): n(\mathrm{CA})=1: 1$ was found to be the optimum one to obtain monophase spinel $\mathrm{MgAl}_{2} \mathrm{O}_{4}$. In such a case we observe the most intensive crystallization and spinel formation begins at lower temperature compared with other ratios. The temperature of $1273 \mathrm{~K}$ and isothermal keeping for $3 \mathrm{~h}$ were found to be the optimal parameters for the powder synthesis. According to XRD and Rietveld technique data (Table 2) all reflexes at the diffractogram (Fig. 2) correspond to the spinel structure. Other crystalline phases were not observed.
XRD analyses the partial introduction of $\mathrm{Cr}^{3+}$ ions in both positions ( $\mathrm{Mg}$ and $\mathrm{Al})$ and formation of the solid solution $\mathrm{Mg}_{0.96} \mathrm{Cr}_{0.04} \mathrm{Al}_{1.94} \mathrm{Cr}_{0.06} \mathrm{O}_{4+\delta}$. The $\mathrm{Zr}^{4+}$ ion is included in the spinel structure, substituting only $\mathrm{Mg}^{2+}$ with formation of the solid solution $\mathrm{Mg}_{0.98} \mathrm{Zr}_{0.02} \mathrm{Al}_{2} \mathrm{O}_{4+\delta}$. The size of the spinel powder particles, calculated according to the Scherrer formula, is within the range of $47-52 \mathrm{~nm}$.

$\mathrm{S}-\mathrm{TiO}_{2}$ powders. The results of the research revealed that it is advisable to perform hydrolysis of TBO in butanol, since the solutions obtained are not segregated and remain stable for a long time. According to XRD data the sols dried at 293 and $393 \mathrm{~K}$ are close in composition and contain one crystalline compound - thiourea $\left(\mathrm{NH}_{2}\right)_{2} \mathrm{CS}$. The increase in the sol drying temperature to $513 \mathrm{~K}$ leads to the disappearance of TU crystals and the appearance of $\mathrm{TiO}_{2}$, which is crystallized in the form of a significantly deformed anatase-like phase, which is confirmed by the DTA data [10]. 
XES indicates the presence of sulfur in $\mathrm{TiO}_{2}$ powder in the amount of $0.7 \mathrm{wt} \%$. Thus, we can assume that in the temperature range from 393 to $513 \mathrm{~K}$, the formation of an anatase crystalline lattice and the incorporation of sulfur ions into its structure occurs, which is actually a modification process. It was found that particles of sol based $\mathrm{S}-\mathrm{TiO}_{2}$ powder, which was obtained using butanol as a solvent, are characterized by a lower degree of agglomeration and more uniform distribution of particles in size in comparison with ethanol and water.

According to the SEM results, the particles of dried sols have spherical form with an average diameter of 290-300 nm (Fig. 3).

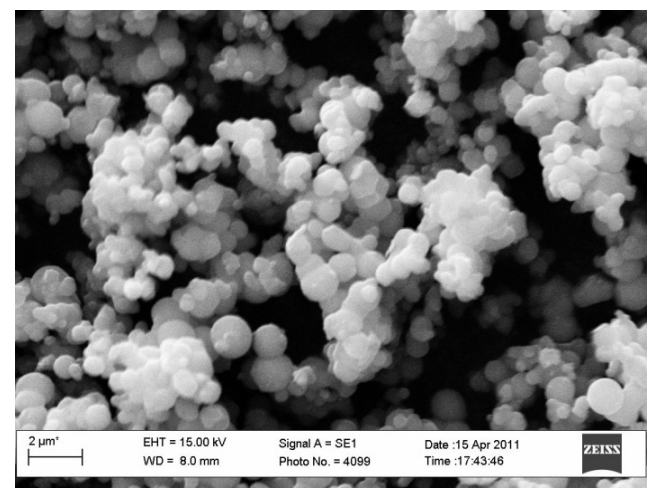

Fig. 3. Micrograph (SEM) of sol sample ( $T_{\text {drying }}-393 \mathrm{~K}, \tau=24 \mathrm{~h}$ )

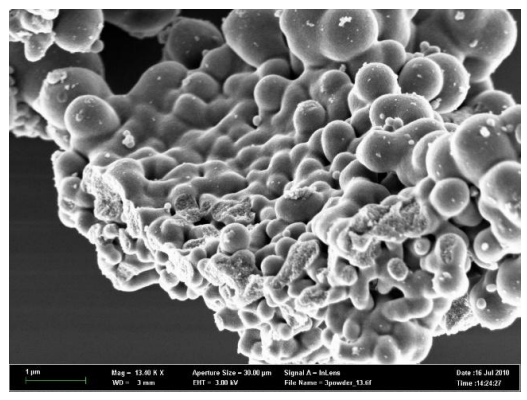

a)

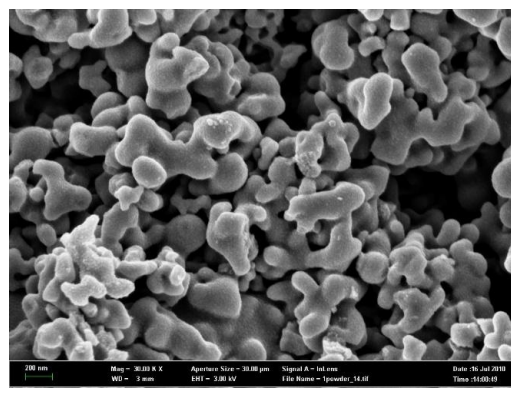

b)

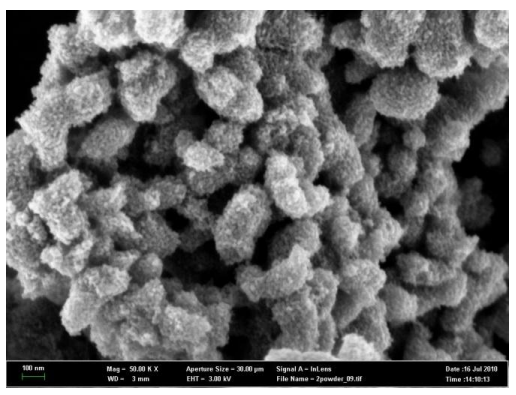

c)

Fig. 4. Micrographs of $\mathrm{S}-\mathrm{TiO}_{2}$ powders under different modes: 1 (a); 2 (b) and 3 (c)

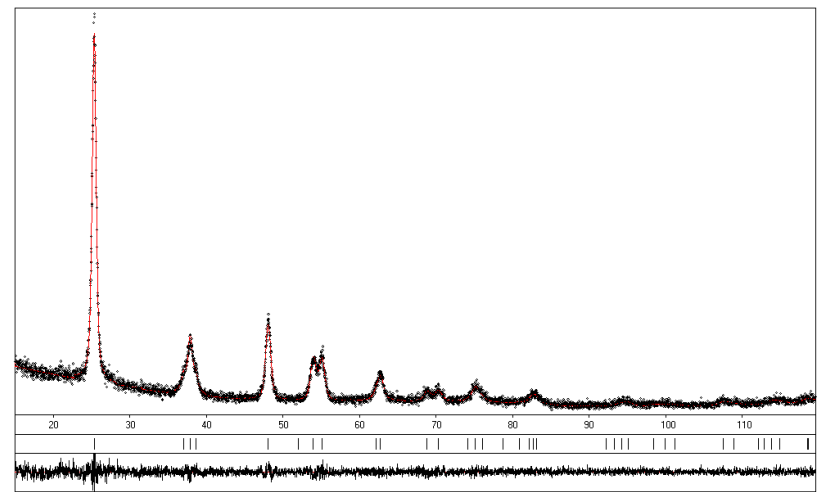

a)

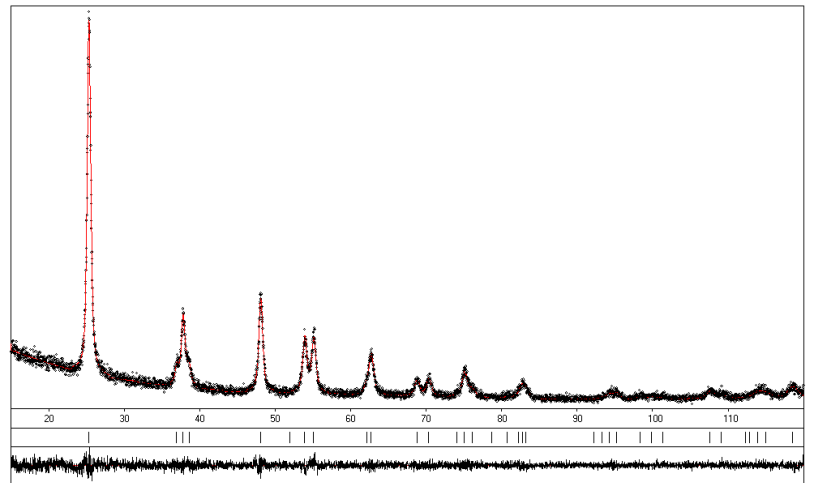

b)

Fig. 5. Diffractograms of $\mathrm{TiO}_{2}$ (a) and $\mathrm{S}-\mathrm{TiO}_{2}$ (b) powders

Table 3

Atomic concentrations of the elements in $\mathrm{S}_{-} \mathrm{TiO}_{2}$ powder

\begin{tabular}{|c|c|c|c|c|}
\hline \multicolumn{4}{|c|}{ Atomic concentration of the element, at \% } & \multirow{2}{*}{$\mathrm{Ti} / \mathrm{S}$} \\
\hline$C$ & $O$ & $T i$ & $S$ & \\
\hline \multicolumn{5}{|c|}{ surface layer } \\
\hline 28.2 & 50.7 & 17.9 & 3.2 & 5.59 \\
\hline \multicolumn{5}{|c|}{ layer at the depth of $1-3 \mu \mathrm{m}$} \\
\hline- & 66.80 & 32.78 & 0.41 & 79.95 \\
\hline
\end{tabular}


The effect of drying conditions on the value and character of the powder specific surface one can see in Fig. 4. The powders treated under modes 2-3 are characterized by more developed specific surface. The sols which were dried at room temperature (mode 1) are agglomerated.

XPS data confirm the presence of sulfur in the form of MeSSMe and (MeOS) $)_{2}$ compounds, and formation of $\mathrm{Ti}-\mathrm{O}-\mathrm{S}$ or $\mathrm{Ti}-\mathrm{S}-\mathrm{O}$ bonds at these stages of sols preparing and drying. It should be noted that the elements concentration in all samples is practically the same.

So, titanium-containing powders must be synthesized under following conditions:

- TBO is hydrolyzed in the medium of butanol as the most effective solvent;

- sols are evaporated in an autoclave to provide the maximum introduction of sulfur into surface layers of $\mathrm{TiO}_{2}$.

- the optimum temperature is $773 \mathrm{~K}$ with isothermal keeping for $1 \mathrm{~h}$.

According to XRD data pure and modified titanium powders are monophase and contain only one crystalline phase with the anatase structure (Fig. 5). The particles size of the $\mathrm{S}-\mathrm{TiO}_{2}$ powder, calculated according to the Scherrer formula, is within the range of $17-19 \mathrm{~nm}$.

The surface composition of $\mathrm{S}^{-\mathrm{TiO}_{2}}$ powder synthesized at $773 \mathrm{~K}$ is represented in Table 3 in accordance with the results of XPS and XES analyses. The highest concentration of sulphur was observed in the surface layer and in the layer at the depth of $1-3 \mu \mathrm{m}$, that is typical for the powder, the sol of which was evaporated according to the mode 3 .

When comparing the results, one can see that the elemental composition of the powder at the depth of 1$3 \mu \mathrm{m}$ essentially differs from that at the surface $(\mathrm{Ti} / \mathrm{S} \sim 80$ $v s$. Ti/S 6). Hence, we assume that sulphur-containing particles segregate over the $\mathrm{TiO}_{2}$ surface.

Thus, $\mathrm{TiO}_{2}$ is modified by sulphur as follows: sulphur-containing particle with the diameter of $\sim 10 \mathrm{~nm}$ segregate to the surface of anatase crystals with the diameter of $\sim 20 \mathrm{~nm}$; the formed globules create nanostructured spheres with an average diameter of $\sim 1 \mu \mathrm{m}$.

\section{Conclusions}

A heterovalent isomorphic substitution of $\mathrm{Mg}^{2+}$ and $\mathrm{Al}^{3+}$ ions by $\mathrm{Cr}^{3+}, \mathrm{Y}^{3+}$ and $\mathrm{Zr}^{4+}$ ions was established in the structure of forestite and spinel followed by the formation of solid solutions of $\mathrm{Mg}_{1.97} \mathrm{Cr}_{0.03} \mathrm{SiO}_{4+\delta}, \mathrm{Mg}_{1.99} \mathrm{Y}_{0.01} \mathrm{SiO}_{4+\delta}$,
$\mathrm{Mg}_{1.96} \mathrm{Zr}_{0.04} \mathrm{SiO}_{4+\delta}, \quad \mathrm{Mg}_{0.96} \mathrm{Cr}_{0.04} \mathrm{Al}_{1.94} \mathrm{Cr}_{0.066} \mathrm{O}_{4+\delta}, \quad$ and $\mathrm{Mg}_{0.98} \mathrm{Zr}_{0.02} \mathrm{Al}_{2} \mathrm{O}_{4+\delta}$. The formation of the sol-gel powders morphology takes place in accordance with a multi-level scheme, which involves the addition of sulfur-containing particles to anatase crystals in the form of nanoaggregates and formation of spheres with the diameter of $\sim 1 \mu \mathrm{m}$. Implantation of $\mathrm{TiO}_{2}$ structure by sulfur occurs in surface layers of $\sim 5 \mathrm{~nm}$ thickness with the formation of bidentate sulfates.

\section{References}

[1] Pavlovska O., Vasylechko L., Lutsyuk I. et al.: Nanoscale Res. Lett., 2017, 12, 153. https://doi.org/10.1186/s11671-017-1946-7 [2] Swatsitang E., Karaphun A., Phokha S. et al.: J. Sol-Gel Sci. Technol., 2017, 81, 483. https://doi.org/10.1007/s10971-016-4212-z [3] Camilleri J.: The Use of Modified Portland Cement as a Dental Core Build-up Material. Lap Lambert Acad. Publishing 2010.

[4] Lutsyuk I., Vakhula Ya., Levytskyi V., Zhuk L.: Chem. Chem. Technol., 2014, 8, 261.

[5] Udalov Yu., Hermansky A. et al.: Technologia

Neorganicheskykh Poroshkovykh Materialov i Pokrytiy

Funktsionalnogo Nazanachenia. Yanus, Sankt-Peterburg 2001.

[6] Frisch B.: Part. Part. Syst. Char., 1989, 6, 39.

https://doi.org/10.1002/ppsc.19890060106

[7] Semchenko G.: Zol-Gel Process v Keramicheskoi Technologii.

BI, Kharkov 1997.

[8] Semchenko G., Shuteeva I., Butenko A. et al.: Zol-Gel

Kompositsii Polyfunktsionalnogo Naznachenia. Raduga, Kharkob 2011.

[9] Akselrud L., Grin Y.: J. Appl. Cryst., 2014, 47, 803.

https://doi.org/10.1107/S1600576714001058

[10] Vahula Ya., Besaha Kh., Lutsyuk I., Dobrotvorska M.: Chem. Chem. Technol., 2011, 5, 255.

Received: December 12, 2017 / Revised: December 20, 2017 / Accepted: January 24, 2018

\section{ТЕОРЕТИЧНІ АСПЕКТИ МЕХАНІЗМУ МОДИФІКУВАННЯ КЕРАМІЧНИХ ОКСИДНИХ ПОРОШКІВ ТЕХНІЧНОГО ПРИЗНАЧЕННЯ}

Анотація. Наведено результати розроблення рідкофазових технологій високодисперсних керамічних оксидних порошків технічного призначення та способи їх модифікування. На основі фізико-хімічних методів досліджень здійснено аналіз різних за механізмами модифікуючих процесів. У складних оксидних порошках відбувається заміщення основних йонів легуючими з утворенням твердих розчинів. Модифікування $\mathrm{TiO}_{2}$ Сульфуром дає змогу отримати порошок із поверхневим шаром, в якому Сульфур утворює хімічні зв'язки.

Ключові слова: керамічні порошки, структурне модифікування, золь-гель технологія, тверді розчини, йонна імплантація. 